\title{
SRD5A1 wt Allele
}

National Cancer Institute

\section{Source}

National Cancer Institute. SRD5A1 wt Allele. NCI Thesaurus. Code C105159.

Human SRD5A1 wild-type allele is located 5p15 and is approximately $36 \mathrm{~kb}$ in length. This allele, which encodes 3-oxo-5-alpha-steroid 4-dehydrogenase 1 protein, plays a role in the conversion of testosterone into dihydrotestosterone. 